\title{
The Effectiveness of G-Suite Docs on the Students' Writing Skills at SMA Negeri 1 Batuan
}

\author{
Norani Yanuar Subandi ${ }^{1}$, J. Priyanto Widodo ${ }^{2}$, Shierly Novalita Yappi ${ }^{3}$ \\ 1,2,3 STKIP PGRI Sidoarjo, Indonesia \\ nor4ni81@gmail.com,prowidodo18@gmail.com,snovalita@gmail.com
}

\begin{abstract}
The primary goal of this study was to determine the effectiveness of G-Suite Docs on students' writing skills as well as students' perceptions of its implementation at SMA Negeri 1 Batuan. It was carried out on the 40 students in the eleventh grade, who were divided into two groups: control and experiment groups, using an experimental design. The results showed that Ha was accepted and Ho was rejected, indicating that the writing method using $G$ Suite Docs has a significant effect on improving students' writing ability and could be used effectively in writing class. The students' perceptions then demonstrated that using G-suite docs had a significant impact on their writing ability, and they enjoyed writing using the G-suite docs method. It was proven by the Cronbach's Alpha $(\alpha)$ statistical test, with the limitation of a variable being said to be reliable if the Cronbach's Alpha value is $>0.5$ and can be said to be reliable.
\end{abstract}

Keywords

G-Suite Docs; effectiveness; writing skill

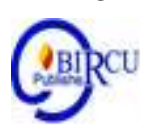

\section{Introduction}

The Covid-19 pandemic has altered many people's lives and had a significant impact on social, economic, and educational life. Sihombing (2020) state that Covid-19 pandemic caused everyone to behave beyond normal limits as usual. The outbreak of this virus has an impact especially on the economy of a nation and Globally (Ningrum, 2020). The problems posed by the Covid-19 pandemic which have become a global problem have the potential to trigger a new social order or reconstruction (Bara, 2021). Education, which is normally done face to face, should be transformed based on the zone of environmental conditions based on public health safety. Regardless of the limitations in education implementation, learning activities must continue to take place. As directed by the Indonesian Minister of Education, Mr. Nadiem Anwar Makarim, education must continue, and the independent learning program must be implemented. In independent learning, the teacher serves as both a learning resource and a facilitator of learning activities. In this role, the teacher must be able to design innovative and enjoyable learning so that students achieve the expected learning objectives (Ilmi et al., 2020). Furthermore, the Ministry of Education and Culture launched a free program that enables learning activities to be carried out effectively and efficiently, namely the Belajar.id account, also known as the Google Suite or Google workspace; which enables teachers and students to carry out teaching and learning activities more effectively with their learning accounts in order to achieve success in the independent program.

Therefore, technology has an important role in English learning activities to support meaningful instructional practices (Sumardi \& Muamaroh, 2020). It is consistent with the 
national standards established by the Minister of Education in National Education Regulation No. 22 of 2016 regarding the standard process of elementary school to high school education units, which state that: the teaching and learning process in an elementary school to high school education unit is interactive, inspiring, fun, and challenging, and encourages students' motivation to participate actively (Cenrikawaty et al., 2020).

Moreover, English teachers must manage proper preparation in the teaching and learning process to help students learn English writing skills according to the 2013 curriculum standard. Writing is one of the four language skills. As Harmer in (Sayar, 2019) stated writing is a process of expressing feelings, thoughts, and ideas in the form of graphic language and is one of the English skills that must be mastered by English learners. While based on (Yudianto, 2017), Writing not only about vocabulary and grammar, but also the ability to construct ideas and organize it in a good writing. An idea in writing is important because it guides students in compiling an essay/writing. And when the students lack of ideas, they will be stuck on what to write in their writing. In this case, the ability to build and organize ideas played a major role in writing. in line with Nunan in (Ningsih, 2016) states that learning writing fluently and expressively is the most difficult of the four language skills for all students whether it is for first, second or foreign language students. Nunan also confirmed that the most difficult thing to do in learning a foreign language is probably in make writing coherent, fluent, and broad.

In the 2013 Curriculum concerning General Guidelines for Learning English in SMA states that the purpose of teaching writing at the Senior High School (SMA) level is so that students can produce various forms of short functional texts and essays. The forms of text that must be produced are discussion, narrative, procedure, descriptive, report, news item, exposition, explanation, discussion, and review (Mulyani, 2018). One of the text must be learned by the students is Analytical Exposition. (Yudianto, 2017) stated that Analytical Exposition is an argumentative text. The purpose of this text is to convince the reader or listener to accept the writer's point of view or take an action that is consistent with that conveyed by the writer. Meanwhile, (Zuana, 2020) explained the generic structure of analytical exposition consists of thesis, argument, and reiteration. Thesis explains the topic which will be talked about. Then the students need to elaborate the evidence to convince the audience called argument to support their ideas. This part is developed and supported by each point/argument. And the last section is the reiteration that restates their position.

After the researcher analyzed the students' problems in writing, the researcher suggested the use of collaborative learning in writing using G-Suite docs in the experimental class. Based on (Yan, 2019), Collaborative learning is a learning strategy in which groups of students at various levels of performance work together and try to solve a problem, complete a task, or create a product. Collaborative learning is based on the idea that learning is a natural social act in which participants talk among themselves actively. Moreover, it is worth mentioning that with today's advances in technology and the use of computers and the Internet in language classes, students have more opportunities to practice collaborative online their writing and collaboration activities are not limited to classroom settings. They can share information and build and exchange knowledge and meaning with each other at all stages of writing process (Challob et al., 2016).

And in this collaborative writing, researcher used G-suite docs or Google workspace in Experimental class. G Suite is one of the integrated services provided by Google for the needs of Business people consisting of: GMail, Docs, Drive, Calendar, Meet, and more other applications. and in 2006, Google was committed to education and launched an application called Google for Education where this application supports educational programs by providing collaboration facilities in learning (Raharjo et al., 2019). Meanwhile, according to 
(Legowo et al., 2019) the Google for Education (G-Suite) is an application from Google that facilitates learning by storing administrative data and cloud-based data making it possible for teachers and students to learn collaboratively with the aim of increasing students' pedagogical abilities with online learning interactions.

Based on the nature of the collaborative learning technique with the G-Suite Docs media above, the researchers assume that this technique is very appropriate to be used to train the writing skills of students who have difficulty. As previous researches of which talking about G-suite; they are: The first related research was conducted by (Basilaia, 2020) explaining about G-suite as an alternative to interactive online teaching by using products that are part of the $\mathrm{G}$ suite for education, such as Gmail, Classroom, Calendar, Forms, Jamboard, Images, Drive, Hangouts meet, and software free Open broadcast studio. But it didn't explain how to use G-suite docs in writing as a detail. Meanwhile, the second related research was conducted by (Mahapatra et al., 2017) also explained about G-suite, in which described Google Suite is an integrated cloud-based service package that provides a new way for organizations to work together online. The advantages are not only limited to personalized business Gmail and instant chat messages, but extend to real-time document collaboration, social media, video conferencing, cloud storage upgrade, eDiscovery, log analysis, audit reports, enhanced security controls \& data loss prevention. This is a set of applications that have proven to be invaluable to organization as it facilitates communication \& sharing of information for quick decision making and follow-up. However, this study was only discussed G-Suite in Business.

And the third previous research conducted by (Legowo et al., 2019) stated that the Google for Education application made it easier to organize cloud-based learning, simplifying education administration and encourage lecturers and students more effective and efficient interactions. G-Suite for Education could serve as a supplement, complement or substitution in order to improve the 4C competence of Student Pedagogical Insights online learning interactions using G Suite for educational application. And in this study, it used collaborative and cooperative learning methods as the current study.

All of the previous researches used the G-Suite application, with the only difference being the research subject and the web tool of G-Suite that was used as the media; where the first and second previous research used the G-Suite application in administration and business; particularly in collaborative works; while the current research used online G-Suite documents, similar to the third previous research in learning, but this current research is completely different from the previous researches.

\section{Research Methods}

\subsection{Subject of the Study}

Research location takes place at SMA Negeri 1 Batuan. It is located on Jalan Raya Lenteng Batuan Sumenep. The study takes place in English class, SMA Negeri 1 Batuan. The participant focused on Eleventh grade of Science Class as the experiment class and Eleventh grade of Social Class as the control class. The subject of the research is the students who followed English course especially writing lesson. The student of Eleventh grade of science class taken is 20 students and Eleventh grade of Social Class taken is 20 students in year $2021 / 2022$.

\subsection{Research Procedures}

The researcher used a pretest-posttest control group quasi-experimental design. According Erkus in (Bayat, 2014), the reason for the quasi-experimental research design is that the participants in the experimental group and the control group were assigned randomly. 
All studies involving in writing were conducted using G-suite media in process writing in the experimental group, while the traditional method was employed for the control group. All experimental procedures in this study were implemented by the researcher.

\subsection{Data Collection Procedures}

The data were collected by using the results of tests (pretest and posttest) in the form of writing composition, observations of student activities in groups and individually which are observed from video recordings, and the results of interviews with students. The tests aimed to measure the students' ability in writing of analytical exposition text and the effectiveness of the treatments. The writing tests were given to the experimental group and the control group. follow:

The treatment in both Experimental group and control group can be described as

\section{a. Experimental Group}

\section{Planning}

In the Planning process; The teacher prepares all the tools that will be used during the research, such as making learning tools, lesson plans, Student worksheets for each meeting, and several other instruments such as learning implementation observation sheets, and student activity observation sheets.

\section{Implementation}

The implementation of learning to write English analytical exposition texts through the application of G-Suite Docs learning media can be described as follows:

1. The teacher opens the lesson and motivates students to take part in the lesson,

2. The teacher conveys the learning objectives, namely so that students are able to write analytical exposition texts by providing examples of the text and identifying the text shown, then from the identification the teacher gives several questions about the contents of the analytical exposition text given.

3. The teacher provides students' understanding of the text by sharing a video of the text material. Explanation of the material includes the definition of the text, communicative purpose, generic structure, language features of the text,

4. Students are given the task to answer some questions about the text that has been read,

5. The teacher explains the steps for implementing collaborative learning techniques using the G-Suite docs media to make it easier for students to complete group assignments,

6. Students are divided into large groups, containing 3 or 4 people by paying attention to heterogeneity, which means mixing students with low, medium and high competence,

7. The teacher asks students to make an outline with the theme "Save our Earth" for students to work on. After being given the same task for each group in the form of an environmental-themed analytical exposition text, students carry out group discussions to write and comment on their group's writings in order to improve the results: in this process, each group must take screen recorder from their writing process using G-Suite docs.

8. After finishing writing, each group presented the results of their respective group work,

9. Teachers and groups who do not appear give an assessment of the presentations of students who appear,

10. The teacher and students reflect on the results of teaching and learning activities and the teacher explains the material at the next meeting to carry out evaluation activities. 


\section{b. Control Group}

\section{Planning}

In the Planning process; The teacher prepares all the tools that will be used during the research, such as making learning tools, lesson plans, Student worksheets for each meeting, and several other instruments such as learning implementation observation sheets, and student activity observation sheets.

\section{Implementation}

The implementation of learning to write English analytical exposition texts manually can be described as follows:

1) The teacher opens the lesson and motivates students to take part in the lesson,

2) The teacher conveys the learning objectives, namely so that students are able to write analytical exposition texts by providing examples of the text and identifying the text shown, then from the identification the teacher gives several questions about the contents of the analytical exposition text given.

3) The teacher provides students' understanding of the text by sharing a video of the text material. Explanation of the material includes the definition of the text, communicative purpose, generic structure, language features of the text,

4) Students are given the task to answer some questions about the text that has been read,

5) The teacher asks students to make individual outlines with the theme "Save Our Earth". After being given the same task, students in the form of environmental-themed analytical exposition text, the teacher asks students to develop it into paragraphs in analytical exposition text,

6) After finishing writing, each student submits their writing in front of the class,

7) Teachers analyzes the student's work and give note about her writing,

8) The teacher and students reflect on the results of teaching and learning activities and the teacher explains the material at the next meeting to carry out evaluation activities.

\subsection{Data Analysis}

As Volistiana citated by (Indrilla \& Ciptaningrum, 2018), To get a student's writing score, the researcher uses a writing rubric. Instrument validity is obtained through content validity. Therefore, the researcher asked for expert judgment to verify the validity of the instrument. For reliability, inter-rater reliability was used where two raters were selected to assess students' writing scores, both pretest and posttest. In this researcher, the researcher applied the validity and reliability instrument by using in SPSS 26 of Writing score and Questioners of Students' perception.

Table 1. Scoring Rubric of Writing

\begin{tabular}{|l|l|}
\hline SCORE & CRITERIA \\
\hline CONTENT \\
\hline 1 & The topic is not clear and the details are not relating to the topic \\
\hline 2 & $\begin{array}{l}\text { The topic is complete and clear but the details are not relating the topic } \\
\text { The topic is complete and clear but the details are almost relating the } \\
\text { topic }\end{array}$ \\
\hline 4 & The topic is complete and clear and the details are relating to the topic \\
\hline ORGANIZATION \\
\hline 1 & $\begin{array}{l}\text { Identification is not complete and descriptions are arranged with misuse } \\
\text { of connectives }\end{array}$ \\
\hline 2 & \begin{tabular}{l} 
Identification is not complete and descriptions are arranged with few \\
\hline
\end{tabular}
\end{tabular}




\begin{tabular}{|c|c|}
\hline & misuse of connectives \\
\hline 3 & $\begin{array}{l}\text { Identification is almost complete and descriptions are arranged with } \\
\text { almost proper connectives }\end{array}$ \\
\hline 4 & $\begin{array}{l}\text { Identification is complete and descriptions are arranged with proper } \\
\text { connectives }\end{array}$ \\
\hline \multicolumn{2}{|c|}{ GRAMMAR } \\
\hline 1 & Frequent grammatical or agreement inaccuracies \\
\hline 2 & Numerous grammatical or agreement inaccuracies \\
\hline 3 & Few grammatical or agreement inaccuracies but not affect on meaning \\
\hline 4 & Very Few grammatical or agreement inaccuracies \\
\hline \multicolumn{2}{|c|}{ VOCABULARY STYLE } \\
\hline 1 & Very poor knowledge of words, word form, and not understandable \\
\hline 2 & Limited range confusing words and word form \\
\hline 3 & Few mis-use of vocabularies, word form, but not change the meaning \\
\hline 4 & Effective choice of words and word form \\
\hline \multicolumn{2}{|c|}{ MECHANICS } \\
\hline 1 & It is dominated by errors of spelling, punctuation and capitalization \\
\hline 2 & It has frequent errors of spelling, punctuation and capitalization \\
\hline 3 & It has occasional errors of spelling, punctuation and capitalization \\
\hline 4 & It $\mathrm{u}$ correct spelling, punctuation and capitalization \\
\hline
\end{tabular}

Adapted from Volistiana citated by (Indrilla \& Ciptaningrum, 2018)

After the data had collected, the researcher conducted several procedures to analyze the data. First, researchers analyzed students' pretest and post test score. Second, the researcher analyzed the students' questionnaire perception which consists of 10 questions. The assessment method used in the questionnaire is Likert scale technique. For each instrument element that uses a Likert scale. The following table responses are indeed very positive to very negative in word patterns:

Tabel 2. Likert Scale

\begin{tabular}{|l|l|l|}
\hline No & Categories & Score \\
\hline 1 & Strongly Agree (SA) & 4 \\
\hline 2 & Agree (A) & 3 \\
\hline 3 & Disagree (D) & 2 \\
\hline 4 & Strongly Disagree (SD) & 1 \\
\hline
\end{tabular}

Adapted from (Basri et al., 2021)

Tabel 3. Questionnaire's Questions

\begin{tabular}{|l|l|}
\hline No. & Questionnaire's Question \\
\hline 1 & $\begin{array}{l}\text { G-Suite offers me more opportunities to interact with my teacher and } \\
\text { peers }\end{array}$ \\
\hline 2 & $\begin{array}{l}\text { G-Suite Docs saves time and effort in writing and submitting assignment } \\
\text { electronically }\end{array}$ \\
\hline
\end{tabular}




\begin{tabular}{|c|c|}
\hline 3 & $\begin{array}{l}\text { G-suite docs gives me a chance to share my writing with my teacher and } \\
\text { peers }\end{array}$ \\
\hline 4 & $\begin{array}{l}\text { G-Suite Docs allows me to get immediate feedback from my Teacher and } \\
\text { peers }\end{array}$ \\
\hline 5 & G-Suite Docs supports e-learning through working in groups. \\
\hline 6 & G-Suite docs allows me to participate in online discussion \\
\hline 7 & G-Suite docs requires long time to master its use \\
\hline 8 & $\begin{array}{l}\text { I need to learn something trouble shooting technology tasks to help } \\
\text { myself when using G-Suite Docs }\end{array}$ \\
\hline 9 & $\begin{array}{l}\text { I dislike using G-Suite Docs because it causes me difficulty in navigating } \\
\text { and typing }\end{array}$ \\
\hline 10 & I get frustrated by using G-suite Docs because of the slow-speed internet \\
\hline
\end{tabular}

SA: Strongly Agree, A: Agree, D: Disagree, SD: Strongly Disagree

Adapted from (Widodo, J. Priyono;Slamet, 2020)

\section{Discussion}

The researcher, in this section, first discusses the research findings related to the research results of students' writing scores and questionnaires distributed to 20 students of eleventh grade science 2 on the implementation of G-suite docs as a means of collaborative writing. Result of Pretest and posttest scores and questionnaires in response to student perceptions are described as follows:

\subsection{The Students' Score of Implementation G-Suite Docs in Writing}

Tabel 4. Students' Score in Writing

Descriptive Statistics

\begin{tabular}{|l|r|r|r|r|r|}
\hline & $\mathrm{N}$ & \multicolumn{1}{|c|}{$\begin{array}{c}\text { Minimu } \\
\mathrm{m}\end{array}$} & \multicolumn{1}{c|}{$\begin{array}{c}\text { Maximu } \\
\mathrm{m}\end{array}$} & \multicolumn{1}{c|}{$\begin{array}{c}\text { Std. } \\
\text { Deviation }\end{array}$} \\
\hline $\begin{array}{l}\text { PreTest } \\
\text { Experimental }\end{array}$ & 20 & 55 & 71 & 62.55 & 4.478 \\
\hline $\begin{array}{l}\text { Post Test } \\
\text { Experiment }\end{array}$ & 20 & 76 & 88 & 84.40 & 3.648 \\
\hline PreTest Control & 20 & 46 & 68 & 59.15 & 4.955 \\
\hline Post Test Control & 20 & 68 & 84 & 76.30 & 4.131 \\
\hline Valid N (listwise) & 20 & & & & \\
\hline
\end{tabular}

Based on the results of the descriptive statistics in students' score writing, it can be described as follows, the number of respondents in the experimental class was 20 students with a minimum pretest score of 55 and a maximum score of 71, while the minimum posttest score was 76 and the maximum value was 88 . The standard deviation value of the pretest was 4,478 and the posttest was 3,648. while in the control group the number of respondents was 20 students with a minimum pretest score of 46 and a minimum score of 68 , while the minimum score for the posttest was 68 and the maximum value was 84 . Meanwhile, the standard deviation of the pretest was 4,955 and the posttest was 4,131 . 
Tabel 5. Tests of Normality

\begin{tabular}{|c|c|c|c|c|c|c|c|}
\hline & \multirow[b]{2}{*}{ Class } & \multicolumn{3}{|c|}{ Kolmogorov-Smirnova } & \multicolumn{3}{|c|}{ Shapiro-Wilk } \\
\hline & & $\begin{array}{c}\text { Statisti } \\
\mathrm{c}\end{array}$ & $\mathrm{df}$ & Sig. & $\begin{array}{c}\text { Statisti } \\
\mathrm{c}\end{array}$ & df & Sig. \\
\hline \multirow[t]{4}{*}{$\begin{array}{l}\text { Students } \\
\text { ' Score }\end{array}$} & $\begin{array}{l}\text { Pretest } \\
\text { Experiment }\end{array}$ & .236 & 20 & .005 & .893 & 20 & .030 \\
\hline & $\begin{array}{l}\text { Posttest } \\
\text { Experiment }\end{array}$ & .238 & 20 & .004 & .836 & 20 & .003 \\
\hline & Pretest Control & .162 & 20 & .178 & .937 & 20 & .212 \\
\hline & Posttest Control & .179 & 20 & .093 & .944 & 20 & .288 \\
\hline
\end{tabular}

From the table above, the significance value (p-value) for the normality test using the Shapiro method, the pretest variable is $0.030(30 \%)$ which means $\mathrm{p}>\alpha ; 30 \%>5 \%$ and the posttest variable is $0.003(3 \%)$ which significance $<0.005(5 \%)$. The conclusion is that $\mathrm{Ha}$ is accepted and $\mathrm{H}_{0}$ is rejected, which means that the data comes from a normally distributed population. In other words, the writing method using G-Suite docs has an impact on improving students' writing ability or G-suite docs method is effectively used in writing class.

\subsection{Students' Perception of Implementation G-Suite Docs in Writing}

Tabel 6. Correlations

\begin{tabular}{|c|c|c|c|c|c|c|c|c|c|c|c|c|}
\hline & & $\mathrm{X} 1$ & $\mathrm{X} 2$ & $\mathrm{X} 3$ & $\mathrm{X} 4$ & X5 & X6 & X7 & X8 & X9 & $\mathrm{X} 10$ & $\begin{array}{c}\text { Tot } \\
\text { al }\end{array}$ \\
\hline \multirow[t]{3}{*}{$\mathrm{X} 1$} & $\begin{array}{l}\text { Pearson } \\
\text { Correlation }\end{array}$ & 1 & $\begin{array}{r}- \\
.096\end{array}$ & .229 & .187 & .150 & .214 & .053 & $\begin{array}{r}- \\
.115\end{array}$ & .019 & $\begin{array}{r}- \\
.053\end{array}$ & .310 \\
\hline & $\begin{array}{l}\text { Sig. (2- } \\
\text { tailed) }\end{array}$ & & .686 & .331 & .429 & .527 & .365 & .826 & .630 & .935 & .826 & .184 \\
\hline & $\mathrm{N}$ & 20 & 20 & 20 & 20 & 20 & 20 & 20 & 20 & 20 & 20 & 20 \\
\hline \multirow[t]{3}{*}{$\mathrm{X} 2$} & $\begin{array}{l}\text { Pearson } \\
\text { Correlation }\end{array}$ & $\begin{array}{r}- \\
.096\end{array}$ & 1 & $.140^{-}$ & 229 & $\begin{array}{r}- \\
.031\end{array}$ & .083 & .096 & $\begin{array}{r}- \\
.210^{-}\end{array}$ &. & $\begin{array}{r}- \\
.096\end{array}$ & $\begin{array}{r}- \\
.076\end{array}$ \\
\hline & $\begin{array}{l}\text { Sig. (2- } \\
\text { tailed) }\end{array}$ & .686 & & .556 & .332 & .898 & .727 & .686 & .374 & .393 & .686 & .749 \\
\hline & $\mathrm{N}$ & 20 & 20 & 20 & 20 & 20 & 20 & 20 & 20 & 20 & 20 & 20 \\
\hline \multirow[t]{3}{*}{ X3 } & $\begin{array}{l}\text { Pearson } \\
\text { Correlation }\end{array}$ & .229 &. & 1 & .408 & .436 & .594 &. & .250 & .085 & .000 & .776 \\
\hline & $\begin{array}{l}\text { Sig. (2- } \\
\text { tailed) }\end{array}$ & .331 & .556 & & .074 & .054 & .006 & .331 & .288 & .722 & $\begin{array}{r}1.00 \\
0 \\
\end{array}$ & .000 \\
\hline & $\mathrm{N}$ & 20 & 20 & 20 & 20 & 20 & 20 & 20 & 20 & 20 & 20 & 20 \\
\hline \multirow[t]{3}{*}{$\mathrm{X} 4$} & $\begin{array}{l}\text { Pearson } \\
\text { Correlation }\end{array}$ & .187 &. & .408 & 1 & .356 & .277 & $\begin{array}{r}- \\
.187 \\
\end{array}$ & .102 & .277 & $\begin{array}{r}- \\
.047 \\
\end{array}$ & $\begin{array}{r}.598 \\
* *\end{array}$ \\
\hline & $\begin{array}{l}\text { Sig. (2- } \\
\text { tailed) }\end{array}$ & .429 & .332 & .074 & & .123 & .237 & .429 & .669 & .237 & .845 & .005 \\
\hline & $\mathrm{N}$ & 20 & 20 & 20 & 20 & 20 & 20 & 20 & 20 & 20 & 20 & 20 \\
\hline \multirow[t]{3}{*}{$\mathrm{X} 5$} & $\begin{array}{l}\text { Pearson } \\
\text { Correlation }\end{array}$ & .150 &. & .436 & .356 & 1 & .315 & $\begin{array}{r}- \\
.150 \\
\end{array}$ & $\begin{array}{r}- \\
.218 \\
\end{array}$ & .130 & $\begin{array}{r}- \\
.100 \\
\end{array}$ & .558 \\
\hline & $\begin{array}{l}\text { Sig. (2- } \\
\text { tailed) }\end{array}$ & .527 & .898 & .054 & .123 & & .177 & .527 & .355 & .586 & .674 & .011 \\
\hline & $\mathrm{N}$ & 20 & 20 & 20 & 20 & 20 & 20 & 20 & 20 & 20 & 20 & 20 \\
\hline
\end{tabular}




\begin{tabular}{|c|c|c|c|c|c|c|c|c|c|c|c|c|}
\hline \multirow[t]{3}{*}{ X6 } & $\begin{array}{l}\text { Pearson } \\
\text { Correlation }\end{array}$ & .214 & $\begin{array}{r}- \\
.083\end{array}$ & $\begin{array}{r}.594 \\
* * * \\
\end{array}$ & .277 & .315 & 1 & .214 & .042 & .065 & .019 & .690 \\
\hline & $\begin{array}{l}\text { Sig. (2- } \\
\text { tailed) }\end{array}$ & .365 & .727 & .006 & .237 & .177 & & .365 & .859 & .786 & .935 & .001 \\
\hline & $\mathrm{N}$ & 20 & 20 & 20 & 20 & 20 & 20 & 20 & 20 & 20 & 20 & 20 \\
\hline \multirow[t]{3}{*}{$\mathrm{X} 7$} & $\begin{array}{l}\text { Pearson } \\
\text { Correlation }\end{array}$ & .053 & .096 & $\begin{array}{r}- \\
.229\end{array}$ & $\begin{array}{r}- \\
.187\end{array}$ & $\begin{array}{r}- \\
.150\end{array}$ & $\begin{array}{r}- \\
.214\end{array}$ & 1 & .115 & $\begin{array}{r}- \\
.019\end{array}$ & .053 & $\begin{array}{r}- \\
.046\end{array}$ \\
\hline & $\begin{array}{l}\text { Sig. (2- } \\
\text { tailed) }\end{array}$ & .826 & .686 & .331 & .429 & .527 & .365 & & .630 & .935 & .826 & .847 \\
\hline & $\mathrm{N}$ & 20 & 20 & 20 & 20 & 20 & 20 & 20 & 20 & 20 & 20 & 20 \\
\hline \multirow[t]{3}{*}{$\mathrm{X} 8$} & $\begin{array}{l}\text { Pearson } \\
\text { Correlation }\end{array}$ & .115 & $\begin{array}{r}- \\
.210\end{array}$ & .250 & $\begin{array}{r}- \\
.102\end{array}$ & $\begin{array}{r}- \\
.218\end{array}$ & .042 & .115 & 1 & $\begin{array}{r}- \\
.170\end{array}$ & $\begin{array}{r}- \\
.115\end{array}$ & .101 \\
\hline & $\begin{array}{l}\text { Sig. (2- } \\
\text { tailed) }\end{array}$ & .630 & .374 & .288 & .669 & .355 & .859 & .630 & & .475 & .630 & .673 \\
\hline & $\mathrm{N}$ & 20 & 20 & 20 & 20 & 20 & 20 & 20 & 20 & 20 & 20 & 20 \\
\hline \multirow[t]{3}{*}{ X9 } & $\begin{array}{l}\text { Pearson } \\
\text { Correlation }\end{array}$ & .019 & $\begin{array}{r}- \\
.202\end{array}$ & .085 & .277 & .130 & .065 & $\begin{array}{r}- \\
.019\end{array}$ & $\begin{array}{r}- \\
.170\end{array}$ & 1 & .019 & .422 \\
\hline & $\begin{array}{l}\text { Sig. (2- } \\
\text { tailed) }\end{array}$ & .935 & .393 & .722 & .237 & .586 & .786 & .935 & .475 & & .935 & .064 \\
\hline & $\mathrm{N}$ & 20 & 20 & 20 & 20 & 20 & 20 & 20 & 20 & 20 & 20 & 20 \\
\hline \multirow[t]{3}{*}{$\mathrm{X} 10$} & $\begin{array}{l}\text { Pearson } \\
\text { Correlation }\end{array}$ & $\begin{array}{r}- \\
.053 \\
\end{array}$ & $\begin{array}{r}- \\
.096 \\
\end{array}$ & .000 & $\begin{array}{r}- \\
.047 \\
\end{array}$ & $\begin{array}{r}- \\
.100 \\
\end{array}$ & .019 & .053 & $\begin{array}{r}- \\
.115 \\
\end{array}$ & .019 & 1 & .178 \\
\hline & $\begin{array}{l}\text { Sig. (2- } \\
\text { tailed) }\end{array}$ & .826 & .686 & $\begin{array}{r}1.00 \\
0 \\
\end{array}$ & .845 & .674 & .935 & .826 & .630 & .935 & & .453 \\
\hline & $\mathrm{N}$ & 20 & 20 & 20 & 20 & 20 & 20 & 20 & 20 & 20 & 20 & 20 \\
\hline \multirow[t]{3}{*}{$\begin{array}{l}\text { Tot } \\
\text { al }\end{array}$} & $\begin{array}{l}\text { Pearson } \\
\text { Correlation }\end{array}$ & .310 & $\begin{array}{r}- \\
.076 \\
\end{array}$ & $\begin{array}{r}.776 \\
* *\end{array}$ & $\begin{array}{r}598 \\
* *\end{array}$ & .558 & .690 & $\begin{array}{r}- \\
.046 \\
\end{array}$ & .101 & .422 & .178 & 1 \\
\hline & $\begin{array}{l}\text { Sig. (2- } \\
\text { tailed) }\end{array}$ & .184 & .749 & .000 & .005 & .011 & .001 & .847 & .673 & .064 & .453 & \\
\hline & $\mathrm{N}$ & 20 & 20 & 20 & 20 & 20 & 20 & 20 & 20 & 20 & 20 & 20 \\
\hline
\end{tabular}

The validity of each item is indicated by the total column in Table 6. Based on the $\mathrm{r}$ table, the minimum Pearson Correlation value is 0.076 because it uses 20 respondents $(\mathrm{N})$ with a limit of 0.05 . It can be seen that all Pearson correlations values for each item are above 0.076 . This is indicated by a $*$ or $* *$ mark in the Total column in the output table. So that, the 10 items of this questionnaire are valid.

And the measurement of reliability is measured by the Cronbach's Alpha $(\alpha)$ statistical test, with the limitation of a variable being said to be reliable if the Cronbach's Alpha value is $>0.5$. The results of the Cronbach's Alpha measurement can be seen in table 7 below, where the detailed data of SPSS output results can be concluded that the variable perception of students towards the implementation of G-suite docs can be said to be reliable, because the Cronbach's Alpha value is $>0.5$, i.e., p-value $>0.5=38.9>0.5$. In other words, the students' perception toward implementing G-suite docs in writing class gives many impacts on improving their writing ability and they feel happy writing using G-suite docs method. 


\begin{tabular}{|c|c|c|}
\hline \multicolumn{3}{|c|}{ Tabel 7. Reliability Statistics } \\
\hline Cronbach's Alpha & $\begin{array}{c}\text { Cronbach's Alpha } \\
\text { Based on Standardized } \\
\text { Items }\end{array}$ & $\mathrm{N}$ of Items \\
\hline .389 & .267 & 10 \\
\hline
\end{tabular}

The last statement focuses on additional perceptions of the implementation of the GSuite document in writing texts. Surprisingly, the results showed a positive response given by students. There are several perception in the implementation of the G-Suite document. (1) GSuite is a viable solution applied during a pandemic where we have to keep our distance, so it is very useful; (2) G-suite documents help me learn more, communicate and write texts as our teacher's task in the current situation; (3) G-Suite documents are effective online learning; (4) G-Suite documents help us in the learning process, especially in the writing class; and (5) We find that the G-Suite document can accommodate the need interactive learning because we can share ideas and our partners can complete our paragraphs.

However, there are also obstacles encountered in the implementation of G-suite, including: 1. when the network is less stable, and 2. when the writing partner is less proactive in completing the writings of this group so that other members must be more active in completing the text. But in general, G-suite docs are very helpful and become an interactive medium that makes students more creative and enthusiastic in writing English texts.

\section{Conclusion}

This chapter consists of two sections; the first section deals with conclusion of the research's finding and discussion, and the second section deals with suggestion.

\subsection{Conclusion}

Based on the finding and discussion of the research, the researchers concluded that

1. The use of G-suite docs is effective to improve the students' writing ability in terms of content, organization, grammar, vocabulary styles, and mechanics. It is proven by the significance value ( $\mathrm{p}$-value) for the normality test using the Shapiro method, the pretest variable is $0.030(30 \%)$ which means $p>\alpha ; 30 \%>5 \%$ and the posttest variable is $0.003(3 \%)$ which significance $<0.005(5 \%)$. The conclusion is that $\mathrm{Ha}$ is accepted and $\mathrm{HO}$ is rejected, which means that the data comes from a normally distributed population. In other words, the writing method using G-Suite docs has an impact on improving students' writing ability or G-suite docs method was effectively used in writing class.

2. The students' perception shows that the use G-suite docs gives many impacts for their writing ability and they feel happy writing using G-suite docs method. It is proven by the measurement of reliability is measured by the Cronbach's Alpha $(\alpha)$ statistical test, with the limitation of a variable being said to be reliable if the Cronbach's Alpha value is $>0.5$. The results of the Cronbach's Alpha measurement can be seen in table 7 below, where the detailed data of SPSS output results can be concluded that the variable perception of students towards the implementation of G-suite docs can be said to be reliable, because the Cronbach's Alpha value is $>0.5$, i.e. p-value $>0.5 ; 38.9>$ 0.5 .

\subsection{Suggestion} follow

Based on the result of the data analysis and conclusion, the researcher suggests as 
1. It is suggested to the English teachers to use G-suite docs method as the alternative in the teaching learning process to improve the students English skill, especially in improving their writing ability,

2. The students are expected to improve their intensity in learning writing through G-suite docs method,

3. This strategy can be used as an additional strategy on further research with different discussion for the next researcher.

\section{References}

Bara, A., et.al. (2021). The Effectiveness of Advertising Marketing in Print Media during the Covid 19 Pandemic in the Mandailing Natal Region. Budapest International Research and Critics Institute-Journal (BIRCI-Journal) Vol 4 (1): 879-886.

Basilaia, G. (2020). Replacing the Classic Learning Form at Universities as an Immediate Response to the COVID-19 Virus Infection in Georgia. International Journal for Research in Applied Science and Engineering Technology, 8(3), 101-108. https://doi.org/10.22214/ijraset.2020.3021

Basri, M., Husain, B., \& Modayama, W. (2021). University Students' Perceptions in Implementing Asynchronous Learning during Covid-19 Era. Metathesis: Journal of English Language, Literature, and Teaching, 4(3), 263. https://doi.org/10.31002/metathesis.v4i3.2734

Bayat, N. (2014). Sürece dayali \{dotless\} yazma yaklaşi\{dotless\}mi\{dotless\}ni \{dotless\}n yazma başari \{dotless\} si \{dotless\} ve kaygi\{dotless\} si \{dotless\} üstündeki etkisi. Kuram ve Uygulamada Egitim Bilimleri, 14(3), 1123-1141. https://doi.org/10.12738/estp.2014.3.1720

Cenrikawaty, Y., Mukhaiyar, M., Yasin, A., \& Abdul Manaf, N. (2020). The english teachers' management for the preparation in teaching and learning process of genre based writing instruction in 2013 curriculum at senior high school in pesisir selatan regency. 3, 107-114. https://doi.org/10.32698/tech3243

Challob, A. I., Bakar, N. A., \& Latif, H. (2016). Collaborative Blended Learning Writing Environment: Effects on EFL Students' Writing Apprehension and Writing Performance. English Language Teaching, 9(6). https://doi.org/10.5539/elt.v9n6p229

Ilmi, Z., Darma, D. C., \& Azis, M. (2020). Independence in Learning, Education Management, and Industry 4.0: Habitat Indonesia during COVID-19. Journal of Anthropology of Sport and Physical Education, 4(4), 63-66. https://doi.org/10.26773/jaspe.201010

Indrilla, N., \& Ciptaningrum, D. S. (2018). An approach in teaching writing skills: does it offer a new insight in enhancing students' writing ability. Journal: A Journal on Language and Language Teaching, 21(2), 124-133.

Legowo, B., Kusharjanta, B., Sutomo, A. D., \& Wahyuningsih, D. (2019). Increasing Competency 4C using The G-Suite Application for Education. International Journal of Active Learning, 4(2).

Mahapatra, T., Chopra, M., \& Mahapatra, C. (2017). Google Suite An Integrated IT application for Improved Business Efficiency. International Journal of Computer Sciences and Engineering, 5(10), 276-279. https://doi.org/10.26438/ijcse/v5i10.276279

Mulyani. (2018). Analisis Teks Kompetensi Dasar Pada Silabus Bahasa Inggris Sma/Ma/Smak/Mak Kemdikbud 2017. Jurnal Dimensi Pendidikan Dan Pembelajaran, 6(2), 54-59. 
Ningrum, P.A., Hukom, A., and Adiwijaya, S. (2020). The Potential of Poverty in the City of Palangka Raya: Study SMIs Affected Pandemic Covid 19. Budapest International Research and Critics Institute-Journal (BIRCI-Journal) Vol 3 (3): 1626-1634.

Ningsih, S. (2016). Guided Writing to Improve the Students' Writing Ability of Junior High School Students. Efl Journal, 1(2). https://doi.org/10.21462/eflj.v1i2.12

Raharjo, W. S., Sebastian, D., Chrismanto, A. R., \& Saputra, L. K. P. (2019). Pemanfaatan G Suite for Education untuk Meningkatkan Efektivitas Belajar Mengajar dan Kapasitas Guru SMA. Prosiding Seminar Nasional Hasul Pengabdian Kepada Masyarakat, 4(November).

Sayar, F. (2019). Journal of English language teaching: Mar-Apr19. Journal of Chemical Information and Modeling, 53(9), 1689-1699. http://dergipark.gov.tr/cumusosbil/issue/4345/59412

Sihombing, E.H., and Nasib. (2020). The Decision of Choosing Course in the Era of Covid 19 through the Telemarketing Program, Personal Selling and College Image. Budapest International Research and Critics Institute-Journal (BIRCI-Journal) Vol 3 (4): 28432850 .

Sumardi, S., \& Muamaroh, M. (2020). Edmodo impacts: Mediating digital class and assessment in english language teaching. Cakrawala Pendidikan, 39(2), 319-331. https://doi.org/10.21831/cp.v39i2.30065

Widodo, J. Priyono;Slamet, J. (2020). Students' Perception Towards Google Classroom as ELearning Tool. ISSN 2622-7959 Edisi No. 48 Oktober 2020, 9(May), 6. https://www.slideshare.net/maryamkazemi3/stability-of-

colloids\%0Ahttps://barnard.edu/sites/default/files/inline/student_user_guide_for_spss.p df\%0Ahttp://www.ibm.com/support\%0Ahttp://www.spss.com/sites/dmbook/legacy/ProgDataMgmt_SPSS17.pdf\%0Ahttps://www.n

Yan, L. (2019). A Study on WeChat-Based Collaborative Learning in College English Writing. English Language Teaching, 12(6), 1. https://doi.org/10.5539/elt.v12n6p1

Yudianto, F. (2017). Teaching Writing Analytical Exposition Text By Using Team WordWebbing Technique. Jurnal Pendidikan Dan Pembelajaran Untan, 6(6), 216038.

Zuana, M. M. M. (2020). an Analysis of Students' Writing Assignment of Analytical Exposition Text. JETAL: Journal of English Teaching \& Applied Linguistic, 2(1), 1423. https://doi.org/10.36655/jetal.v2i1.189 